\title{
OBTAINING AND CHARACTERIZING PHOSPHATIC PORCELAIN
}

\author{
Florentina POTECASU, Petrică ALEXANDRU \\ "Dunarea de Jos" University of Galati, Romania \\ e-mail: florentina.potecasu@ugal.ro
}

\begin{abstract}
The research aimed to obtain phosphate porcelain, by using the ash resulting from burning bones from meat processing plants. The applied processing technology allows obtaining fine ceramics at lower temperatures than the one used in the case of feldspar porcelain, having as effect the increase of the durability of the firing furnaces and the realization of the products at lower production costs. Five series of phosphate porcelain samples were performed in laboratory conditions, with different compositions, by firing at a temperature of $1250{ }^{\circ} \mathrm{C}$, temperatures lower than those necessary for the firing of feldspar porcelain of 1350-1450 ${ }^{\circ} \mathrm{C}$. The porosity and density of the samples were determined and the microstructural analysis of the materials made in the five research variants was made.
\end{abstract}

KEYWORDS: phosphate porcelain, kaolin, quartz, porosity, density, microstructural analysis

\section{Introduction}

The notion of pottery has retained its original meaning given by the word "keramos", which in ancient Greek meant the land of the potter and his pots [1-5]. Over time, however, this notion has gained a broader meaning, encompassing all pottery and porcelain products obtained by burning ceramic masses, both domestic, utilitarian or decorative, and industrial [6-9]. Modern ceramics has industrial applications in high temperature areas in the electrical, nuclear, space, etc. With such materials, the shuttles that cross the cosmic space are lined, car engines are made, the entrails of the earth are drilled or the human bone is replaced in difficult surgical operations [8-13].

Over time, aesthetic education through ceramics has left its mark on people. It is felt spontaneously since childhood, due to the daily contact with the surrounding ceramic objects, in different hypostases. Porcelain, as a technical material, has very valuable properties: high mechanical and electrical resistance, chemical and thermal stability, as well as exceptional ornamental possibilities. The structurally component elements of the porcelain material unevenly influence the strength, white colour, transparency and other properties $[6,8,9]$. Porcelain, nicknamed in German as "Weißes Gold" (white gold), is a white and translucent ceramic material obtained by burning at high temperatures a paste composed of quartz, kaolin and feldspar together with smaller additions of other components. It is used in the manufacture of industrial or laboratory vessels, electrical insulators, household vessels or decorative objects. According to the ratio of the components it can be classified as hard porcelain or soft porcelain. For classic hard porcelain the ratio between kaolin, feldspar and quartz is $50 / 25 / 25$, while for soft porcelain it is about $30 / 30 / 40$ [14].

The structure of the porcelain material and its most important properties are determined both by the quantitative properties of the material components and by the firing regime, i.e., the firing temperature and duration, as well as the character of the atmosphere from different firing periods [6, 9].

Phosphate porcelain is a special type of soft paste porcelain, called "oschina", because its main component is bone ash; was discovered in Staffordshire in the late 1700s and was adopted by most English factories in the early 1800s [6, 8]. The precise ratios between the components as well as the processing technology are not completely known.

Phosphate porcelain is part of the oxide system $\mathrm{RO}-\mathrm{Al}_{2} \mathrm{O}_{3}-\mathrm{SiO}_{2}-\mathrm{P}_{2} \mathrm{O}_{5}$. By converting total $\mathrm{RO}$ to $\mathrm{CaO}$, its composition can be located in the domain around the eutectic corresponding to the tricalcium phosphate-anorthite-silicon dioxide subsystem $\mathrm{Ca}_{3}$ $\left.\left(\mathrm{PO}_{4}\right) 2-\mathrm{CaAl}_{2} \mathrm{Si}_{2} \mathrm{O}_{8}-\mathrm{SiO}_{2}\right]$. Phosphate porcelain is characterized by a high content of glassy phase; in the vitreous matrix there is a distribution, especially, of 
tricalcium and anorthite phosphate crystals and to a small extent quartz.

\section{Experimental research}

The research aimed at carrying out in laboratory conditions a series of phosphate porcelain samples symbolized R1, R2, R3, R4, R5. To obtain phosphate porcelain, the basic raw material is the calcined bones meal, which represents $35-60 \%$ of the gross mass (the final preparation is done by degreasing but also by removing gelatin and $\mathrm{Fe}$ oxides).

Five series of samples with different compositions were performed in laboratory conditions:

R1 - Kaolin 25\%; Feldspar 20\%; Quartz 15\%; $40 \%$ bone ash.

R2 - 25\% kaolin; Feldspar 13\%; Quartz 12\%; $50 \%$ bone ash.

R3 - Kaolin 20\%; Feldspar 15\%; Quartz 15\%; $50 \%$ bone ash. ash.

R4 - 40\% kaolin clay; Feldspar 20\%; $40 \%$ bone

R5 - 30\% kaolin clay; Feldspar 15\%; Quartz $5 \% ; 50 \%$ bone ash.

Feldspar is a very common silicate, having the chemical composition ( $\left.\mathrm{Ba}, \mathrm{Ca}, \mathrm{Na}, \mathrm{K}, \mathrm{NH}_{4}\right)(\mathrm{Al}, \mathrm{B}$, Si) 408 (the elements in parentheses can be substituted for each other). The crystallization system for this mineral is monoclinic or triclinic, with a hardness of 6-6.5.

Kaolin is a clay (rock) composed mostly of the mineral kaolinite. Kaolin has a fine granulation $(<2$ $\mu \mathrm{m})$, free of iron oxides, white in colour. Kaolin is a rock with a very fine grain, with a low plasticity, but with high resistance to high temperatures, by burning it becomes solid and very compact (dense).

Quartz (silicon dioxide) is a mineral spread in the earth's crust, which has the chemical composition of $\mathrm{SiO}_{2}$ crystallizing in the trigonal system. In its pure state, quartz is colourless, the impurities in the crystal determine the colour of the mineral. Quartz frequently crystallizes in gaps in rocks called geodes. The cleavage is non-existent, the crack has a pearly colour, reaches a value of 7 on the Mohs hardness scale.

Phosphate porcelain - according to what has been mentioned above, is part of the oxide system $\mathrm{RO}$ - $\mathrm{Al}_{2} \mathrm{O}_{3}-\mathrm{SiO}_{2}-\mathrm{P}_{2} \mathrm{O}_{5}$. Its place in this system converting total $\mathrm{RO}$ to $\mathrm{CaO}$, can be circumscribed to the domain located around the eutectic corresponding to the tricalcium phosphate-anorthite-silicon dioxide subsystem. Phosphate porcelain is characterized by a high glassy phase content; in the vitreous matrix there is a distribution, especially, of tricalcium and anorthite phosphate crystals and to a small extent quartz. Its porosity is very low ( $1 \%$ closed pores).
Phosphate porcelain is characterized by a short glazing interval, which introduces difficulties in the firing of the biscuit (it uses a glaze based on boric frit, easily fusible, applied on products heated to 40-50 degrees $\mathrm{C}$; the second firing must be conducted so as to ensure a good melting and spreading of the glaze.

The porcelain structure consists of:

- isotropic glass mass composed of feldspar glass, with a varying degree of saturation in $\mathrm{Al}_{2} \mathrm{O}_{3}$ and $\mathrm{SiO}_{2}$;

- undissolved and molten particles, as well as dissolved by $\mathrm{Al}_{2} \mathrm{O}_{3}$ and $\mathrm{SiO}_{2}$;

- mullite crystals $3 \mathrm{Al}_{2} \mathrm{O}_{3} \cdot 2 \mathrm{SiO}_{2}$.

Another very important element in the structure of the porcelain mass are the pores, which decrease the quality of the porcelain and cannot be completely removed. Porosity occurs on drying after removal of mechanically distributed water, as well as hygroscopic water from the clay substance, during the initial firing period. The mass has the highest porosity, of about $35 . .40 \%$, before the beginning of vitrification, when the firing is up to $1000 \ldots 1050^{\circ} \mathrm{C}$. As the glass mass forms, the pores fill, the products shrink, the porosity decreases, the mass becomes more compact.

Depending on the temperature and duration of firing, the process of dissolving $\mathrm{Al}_{2} \mathrm{O}_{3}$ and $\mathrm{SiO}_{2}$ in feldspar glass can be more or less complete and therefore the amount and composition of feldspar glass in porcelain mass can vary widely (Fig. 1).

The mass-formed mullite crystals replace in the feldspar glass the granules dissolved by the clay and quartz, thus ensuring the further development of the glass mass and the improvement of the technical indices necessary for the manufacture of insulators and other categories of technical porcelain.

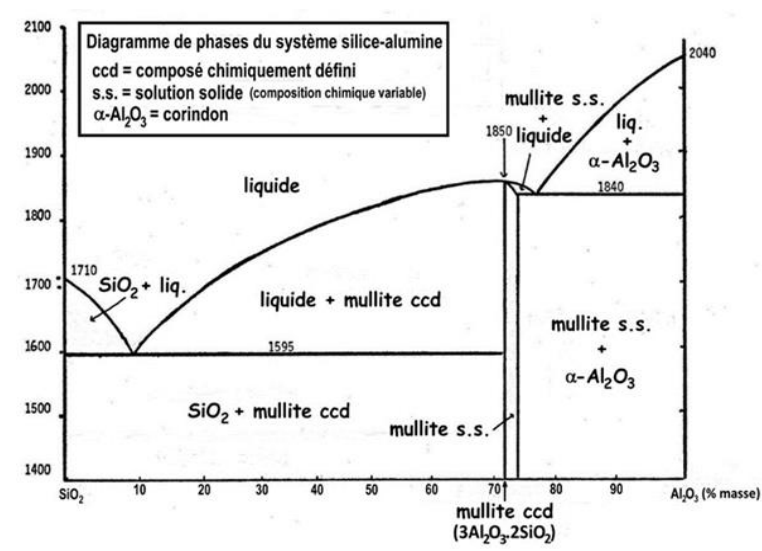

Fig. 1. The binary diagram $\mathrm{SiO}_{2}-\mathrm{Al}_{2} \mathrm{O}_{3}$

An important structural part of porcelain are the quartz granules and undissolved clay substances in the feldspar glass, which together with the crystals of the mullite form the skeleton of the mass, ensuring 
the preservation of the forms produced in the final firing period. The mass remains from $60 \ldots 85 \%$ unmodified quartz.

Another structural element of porcelain are crystalline aluminosilicates, which are formed during firing. When the porcelain is fired, the mullite $3 \mathrm{Al}_{2} \mathrm{O}_{3} \cdot 2 \mathrm{SiO}_{2}$ is formed (Fig. 1) and not the silimanite $\mathrm{Al}_{2} \mathrm{O}_{3} \cdot \mathrm{SiO}_{2}$, as it was assumed before the researches.

The mullite has several valuable properties: high melting start temperature (about $1810{ }^{\circ} \mathrm{C}$ ), high mechanical and electrical resistance, chemical stability, low coefficient of thermal expansion and high thermal stability. The formation of mullite crystals is observed even at a temperature of about $1250{ }^{\circ} \mathrm{C}$.

The research followed two main stages:

- obtaining samples from phosphate porcelain with different compositions, in laboratory conditions, by firing at a temperature of $1250{ }^{\circ} \mathrm{C}$, a temperature

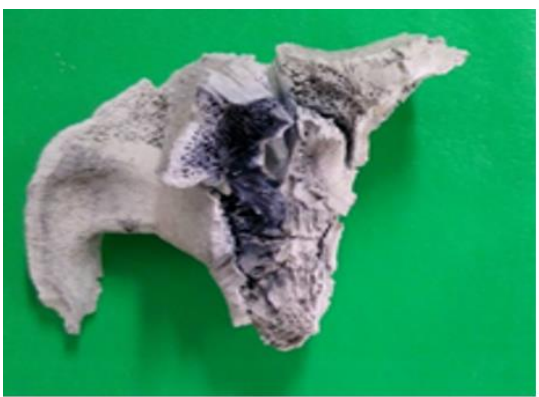

a. lower than that required for firing feldspar porcelain of $1350-1450{ }^{\circ} \mathrm{C}$.

- characterization of the porcelain samples obtained, by determining the porosity, density and analysis under an optical microscope.

\section{Working procedure}

In order to achieve the objectives in obtaining samples of phosphate porcelain with different compositions in laboratory conditions, we proceeded as follows:

Kaolin, feldspar, quartz, bone ash and kaolin clay were used as raw materials. Kaolin, feldspar, quartz and kaolin clay being in a powder state, except for bone ash obtained by grinding calcined pork bones at a temperature of $800{ }^{\circ} \mathrm{C}$ (Fig. 2). With the help of a mortar, we crushed the bones that were burned and calcinated previously.



b.

Fig. 2. Appearance of burnt pork bones at a temperature of 300-400 ${ }^{\circ} \mathrm{C}$ (left side) and calcined bones at a temperature of $800^{\circ} \mathrm{C}$ (right side)

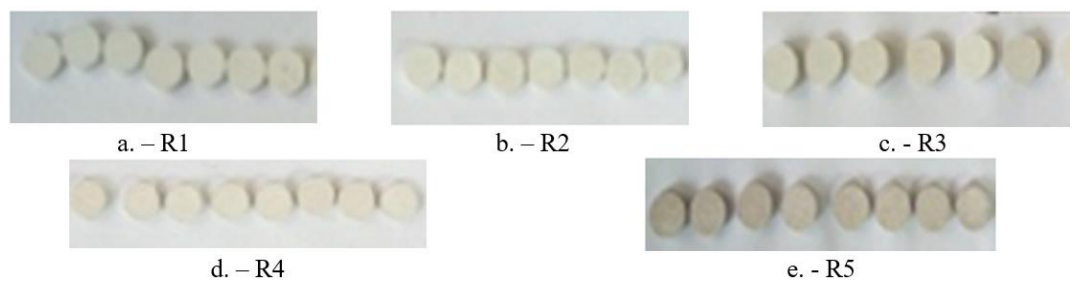

Fig. 3. Samples obtained by pressing

\subsection{Porosity and density of samples}

Porosity was determined by water absorption.

$$
\mathbf{P}=\frac{\Delta m}{m_{0}} * 100[\%]
$$

The pressed samples were fired in an electric oven at $1250{ }^{\circ} \mathrm{C}$ for 2.5 hours, according to the diagram in Figure 4.

After firing, the samples were weighed and measured to determine density, then immersed in boiling water, kept for one hour and then wiped and weighed to determine porosity.

We obtained samples in the form of pills with a diameter of $12.2 \mathrm{~mm}$ and a height between 2.4 and $3.2 \mathrm{~mm}$. The pressing force for all samples was the same, namely $10 \mathrm{kN}$, resulting in a compaction pressure of $85 \mathrm{MPa}$. After pressing, the samples were measured and weighed and determined for the 5 series of porosity and density (Tables 1 and 2).

With the results of the performed determinations, the histograms from Fig. 5 and 6 were made. 


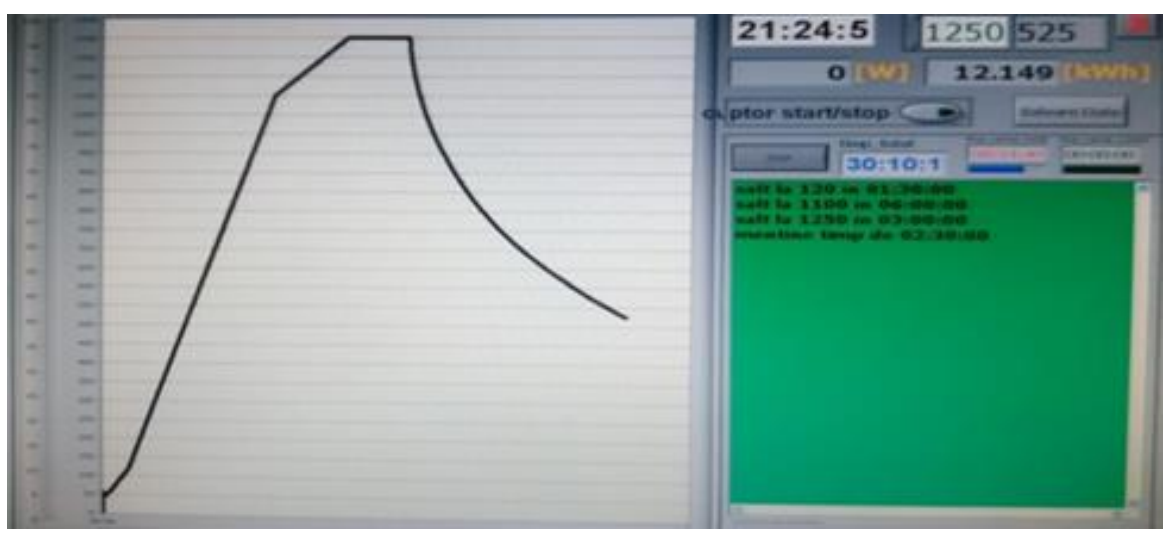

Fig. 4. Firing diagram

Table 1. Determination of sample porosity

\begin{tabular}{|c|c|c|c|c|}
\hline Composition & $\begin{array}{c}\boldsymbol{m}_{\mathbf{0}} \\
{[\mathbf{g}]}\end{array}$ & $\begin{array}{c}\boldsymbol{m}_{\mathbf{1}} \\
{[\mathbf{g}]}\end{array}$ & $\begin{array}{c}\Delta \boldsymbol{m} \\
{[\mathbf{g}]}\end{array}$ & $\begin{array}{c}\text { Porosity } \\
\frac{\Delta \boldsymbol{m}_{\mathbf{0}}}{* \mathbf{1 0 0}[\boldsymbol{\%}]}\end{array}$ \\
\hline R1 & 0.70 & 0.76 & 0.06 & 8.57 \\
\hline R2 & 0.65 & 0.71 & 0.06 & 9.23 \\
\hline R3 & 0.67 & 0.72 & 0.05 & 7.46 \\
\hline R4 & 0.67 & 0,68 & 0.01 & 1.49 \\
\hline R5 & 0.61 & 0.63 & 0.02 & 3.28 \\
\hline
\end{tabular}

$\boldsymbol{m}_{\boldsymbol{0}}$ - mass of the porcelain sample after firing at $1250{ }^{\circ} \mathrm{C}$.

$\boldsymbol{m}_{\boldsymbol{l}}$ - the mass of the sample after being kept in boiled water for one hour.

Table 2. Determination of sample density

\begin{tabular}{|c|c|c|c|c|c|}
\hline Composition & $\begin{array}{c}\boldsymbol{m}_{\mathbf{0}} \\
{[\mathbf{g}]}\end{array}$ & $\begin{array}{c}\mathbf{d} \\
{[\mathbf{m m}]}\end{array}$ & $\begin{array}{c}\mathbf{h} \\
{[\mathbf{m m}]}\end{array}$ & $\begin{array}{c}\mathbf{V} \\
{\left[\mathbf{c m}^{\mathbf{3}}\right]}\end{array}$ & $\begin{array}{c}\boldsymbol{\rho} \\
{\left[\mathbf{g} / \mathbf{c m}^{\mathbf{3}}\right]}\end{array}$ \\
\hline $\mathbf{R} 1$ & 0.70 & 12.1 & 2.8 & 0.327 & 2.14 \\
\hline $\mathbf{R 2}$ & 0.65 & 12.1 & 2.6 & 0.305 & 2.13 \\
\hline $\mathbf{R 3}$ & 0.67 & 11.9 & 2.7 & 0.308 & 2.17 \\
\hline $\mathbf{R 4}$ & 0.67 & 11.8 & 2.6 & 0.288 & 2.32 \\
\hline $\mathbf{R 5}$ & 0.61 & 11.75 & 2.5 & 0.268 & 2.27 \\
\hline
\end{tabular}

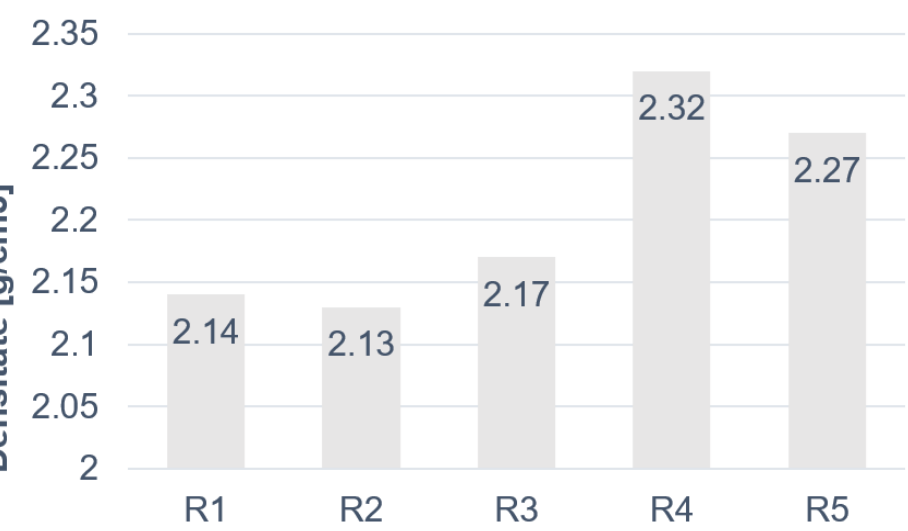

Fig. 5. Density depending on the composition of the porcelain mass fired at a temperature of $1250{ }^{\circ} \mathrm{C}$ 


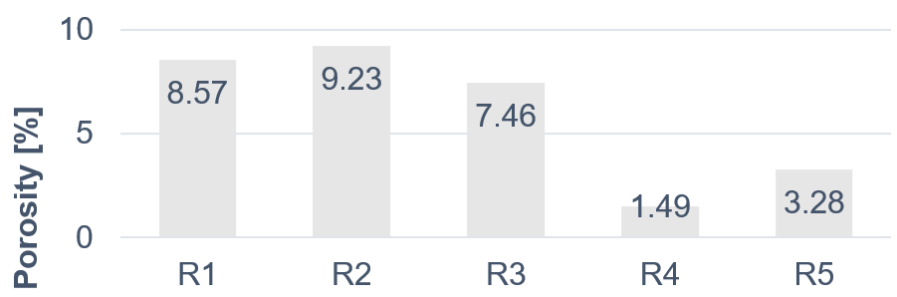

Fig. 6. Porosity depending on the composition of the porcelain mass fired at a temperature of $1250{ }^{\circ} \mathrm{C}$

\subsection{Structural analysis of samples}

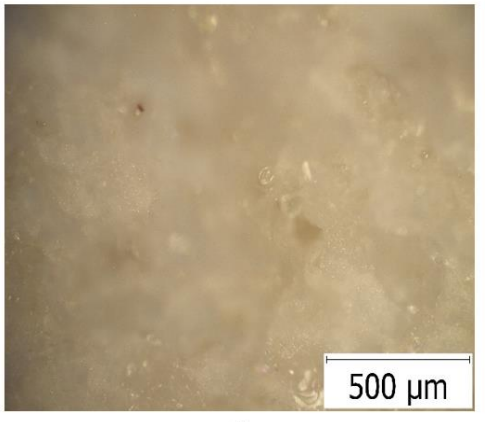

For the study of the structure, the Olympus optical microscope was used both on the pressing surface and in the sample break (Fig. 7-11).

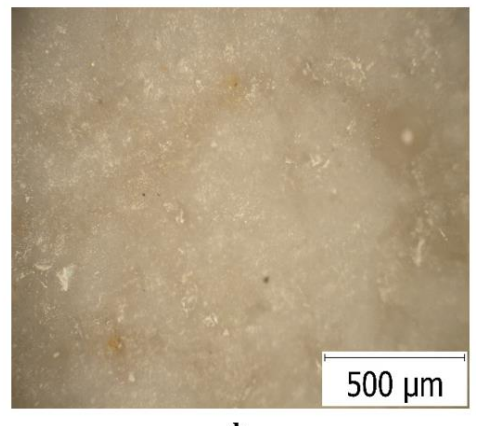

b

Fig. 7. Sample structure R1 (Kaolin 25\%; Feldspar 20\%; Quartz 15\%; Bone ash 40\%, 25\% kaolin). (X100). $a$ - in breaking the sample; $b$-on the surface of the sample



a

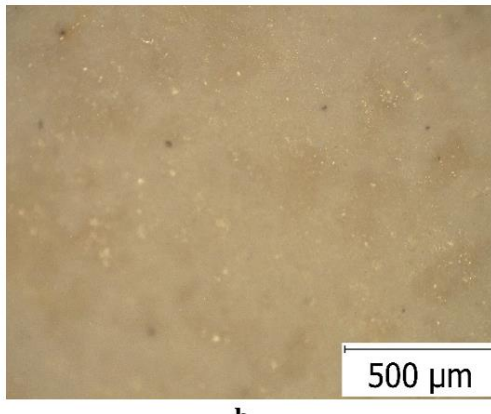

b

Fig. 8. Sample structure R2. (Kaolin 25\%; Feldspar 13\%; Quartz 12\%; Bone ash 50\%.). (X100). a in breaking the sample; $b$-on the surface of the sample

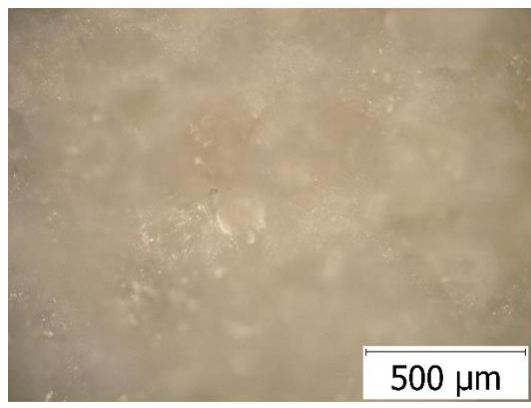



b

Fig. 9. Sample structure R3. (Kaolin 20\%; Feldspar 15\%; Quartz 15\%; Bone Ash 50\%) (X100). a - in breaking the sample; $b$-on the surface of the sample 


\section{THE ANNALS OF “DUNAREA DE JOS” UNIVERSITY OF GALATI \\ FASCICLE IX. METALLURGY AND MATERIALS SCIENCE \\ $\mathrm{N}^{\circ} .4$ - 2020, ISSN 2668-4748; e-ISSN 2668-4756 \\ Article DOI: https://doi.org/10.35219/mms.2020.4.06}
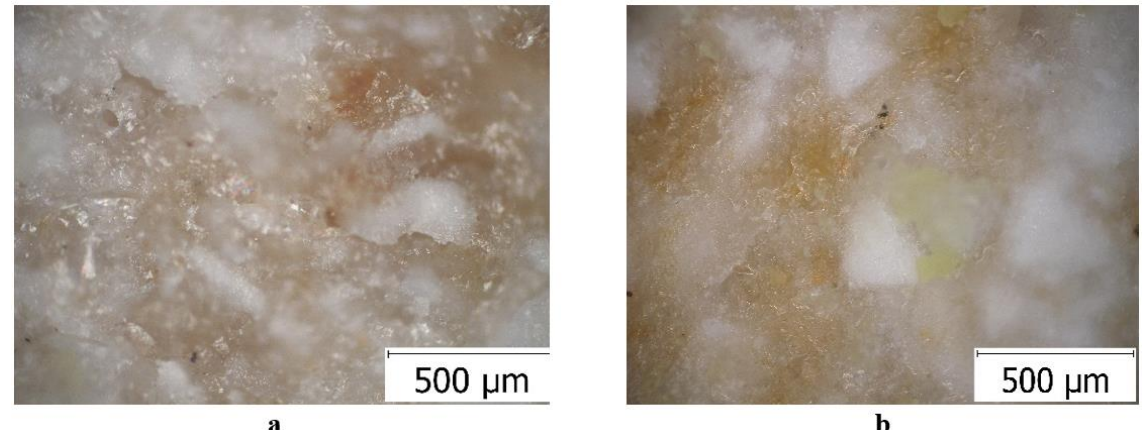

Fig. 10. Sample structure R4 (Kaolin clay 40\%; Feldspar 20\%; Bone ash 40\%). (X100). a - in breaking the sample; $b$-on the surface of the sample





Fig. 11. Sample structure R5. Kaolin clay 30\%; Feldspar 15\%; Quartz 5\%; Bone ash 50\% (X100). ain the sample crack; $b$ - on the sample surface

\section{Conclusions}

The structural aspect studied under the light microscope indicates that in all samples the process of porcelain formation was initiated by the appearance of the glass phase, which partially dissolves the clay substance containing $\mathrm{Al}_{2} \mathrm{O}_{3}$ as well as calcium oxide and phosphorus pentoxide which resulted from the decomposition of phosphate. calcium from bone ash.

Of all the compositions tested, the one marked with R4, which contains kaolin clay instead of kaolin and does not contain quartz, has densified the most with an open and intercommunicating porosity of $1.49 \%$ compared to the maximum porosity obtained in sample R2 of $9.23 \%$. This can be explained by the fact that the kaolin clay used contained free silicon dioxide with micrometric particles and a lower proportion of $\mathrm{Al}_{2} \mathrm{O}_{3}$ than kaolin, which led to the formation of the vitreous phase in a shorter time.

\section{References}

[1]. ***, http://lucia.neagu.com/20180723/lumea-ceramicii/.

[2]. $* * *$ https://www.scribd.com/doc/55666092/EvolutiaCeramicii.

[3]. ***, Dalea I., O istorie a artei ceramice, Editura Meridiane 1987.

[4]. Suter C., Istoria Artei Plastice, vol. 1, Editura Didactica și Pedagogica, Bucuresti.

[5]. Slatineanu B., Ceramica Romaneasca, Studii de arta, Editura de stat, 1958.

[6]. Marincas L., Procedee de fabricare în industria ceramicii, 2006.

[7]. Baltă P., Tehnologia sticlei, Editura tehnică, 1984.

[8]. Patrick Naylor W., Introduction to Metal-Ceramic Technology, Third Edition, 2017.

[9]. Cai Z., Bunce N., Nunn M. E., Okabe T., Porcelain adherence to dental cast CP titanium: effects of surface modifications, Biomaterials, 22 (9), 979-86, 2001 May.

[10]. Hench L. L., Bioceramics J. Am. Cer. Soc., 81 (7), p. 17051728, 1998.

[11]. Hench L. L., Wilson J., An Introduction to Bioceramics, Advanced Series in Ceramics, vol. 1, World Scientific Publishing, 1993.

[12]. Craig R. G., Restorative Dental Materials, Mosby, 1997.

[13]. Forna Norina Consuela, Protetica Dentara, Editura Univers Enciclopedic, Bucuresti, 2011.

[14]. ***, https://ro.wikipedia.org/wiki/Por\%C8\%9Belan. 